\title{
HERBAL LANDSCAPE: THE PERCEPTION OF LANDSCAPE AS A SOURCE OF MEDICINAL PLANTS
}

\author{
Renata Sõukand $^{1,2}$ and Raivo Kalle ${ }^{1}$ \\ ${ }^{1}$ Estonian Literary Museum, Tartu, and ${ }^{2}$ University of Tartu
}

\begin{abstract}
This contribution investigates the idea of herbal landscape, associated with a personal perception of landscape as a source of materia medica. The herbal landscape can be divided into specific smaller units according to several natural and cultural boundaries. This explains why the original knowledge of plants gleaned by one set of inhabitants may be clearly distinguished from that of close neighbors. The natural boundaries are, for example, the habitat (community) and geographical range limit of plants. Cultural boundaries, for example, constitute the cultural space that influences people, the peculiarity of a given language, and the availability of education, popular books and other media regarding plant use. Nevertheless, Estonian natural herbal culture can be viewed as one large-scale herbal landscape.
\end{abstract}

Keywords: ethnobotany, herbal landscape, interpretation, perceived landscape, medicinal plants, Estonia

DOI: $10.3176 /$ tr.2010.3.01

\section{Introduction}

Early ethnobotanical studies were usually focused on simply documenting the traditional botanical knowledge (Guarrera 1999, Giday et al. 2003, Ali-Shtayeh et al. 2000), often taking the data out of its context. In recent times, more attention has been paid to the fact that using wild plants is a relevant component of local traditional ecological knowledge, which requires complex interactions between human beings and their natural resources (Lozada et al. 2006, Eyssartier et al. 2008, Lira et al. 2009, Jarić et al. 2007), and should be looked upon as a complex phenomenon covering historical, geographical, cultural, cross-cultural, economic, social, etc. aspects (Lozada et al. 2006, De Natale 2009, Liu et al. 2009, Molares and Ladio 2009, Thomas et al. 2009b, Vandebroek et al. 2004, Reyes-García et al. 2006). Many researchers have observed different aspects of knowledge transmission (Lozada et al. 2006), trying to apply the Doctrine of Signature to the plant selection process (Bennett 2007, Dafni and Lev 2002), or have explored the categorization 
and the adaptation of plant knowledge (Müller-Schwarze 2006), and there is an ongoing debate about the classification of the environment and its elements that cause certain species to be used and others to be rejected (Rivera et al. 2007).

Although some authors have discovered positive correlation between the accessibility of plant species and their perceived usefulness, indicating that more frequently accessed plants are considered more useful (Thomas et al. 2009a), the mechanisms by which humans identify and choose such specific resources like medicinal plants, remain largely unknown. Moreover, seen as s physical part of the traditional landscape, medicinal plants have rarely been described as an integral part of a wild or cultivated field, perceived as a well-stocked pharmacy available at hand. To fill in this epistemological gap, we introduce the idea of herbal landscape. To the best of our knowledge, this is the first study that defines such an idea. We argue that the idea of herbal landscapes provides ethnobotanists with a new model for understanding the mechanism of perception of medicinal plants.

\section{Defining the study area}

Estonia is located in northern Europe $\left(58^{\circ}-60^{\circ} \mathrm{N}, 22^{\circ}-28^{\circ} \mathrm{E}\right)$ on the eastern coast of the Baltic Sea. Covering an area of $45230 \mathrm{~km}^{2}$, Estonia belongs to the northern part of the temperate zone and to the transition zone between maritime and continental climates (Raukas 1995). The duration of the vegetation period is 185-190 days and the frost-free period is 105-160 days; both are longer on the coast, as is the number of hours of sunshine, which varies between 1600 and 1900 hours. The average duration of snow cover during winter is 75-135 days, characterized by large territorial and temporal variations. The annual average temperature in Estonia $\left(5.2^{\circ} \mathrm{C}\right)$ is higher than that in eastern areas at the same latitude, which have more continental climate. The average temperature in February, the coldest month of the year, is $-5.7^{\circ} \mathrm{C}$. The average temperature in July, which is considered the warmest month of the year, is $16.4^{\circ} \mathrm{C}$. The air humidity is higher in winter and lower in spring, with an average of $82 \%$. The coastal zone receives less rainfall than the inland area, the annual average precipitation varies between 530$750 \mathrm{~mm}$. There are between 102 and 127 rainy days a year.

The vegetation of Estonia is very diverse. Almost half of the territory is covered with forests and about $30 \%$ with peaty soils. Estonia belongs to the boreo-nemoral vegetation zone or to the northern part of the temperate hardwood-coniferous forest zone (Masing et al. 2000). The first scientific studies of Estonian flora originate already from the 18th century, but the first proper list of vascular plants growing in Estonia and Livonia was published by the Baltic German publicist, Estophile and linguist August Wilhelm Hupel (1737-1819) in 1777 in his Topografische Nachricten von Lief- und Ehstland. Since the second half of the 19th century, the flora on the territory of Estonia has been thoroughly studied, making Estonia one of the botanically best described areas in the region (Ö̈̈pik et al. 2008).

Human settlement in Estonia became possible about 11,000 years ago, when the land was freed from the glaciers. Evidence has been found of hunting and fishing 
communities existing around 8900 BC. From approximately the first to fifth centuries $\mathrm{AD}$, resident farming was widely established, the population grew, and settlement expanded. By the end of the 19th century, Estonia had 893,558 inhabitants according to the population census of 1881. 796,809 of them were of Estonian nationality; $86.7 \%$ of the population lived in rural areas. The Estonian language was used mostly among the rural population. Although in 1897, 137 pharmacies were working in the whole of Estonia, these were mostly situated in towns and in parish centers; at the same time, in rural areas there was on average one doctor for 17,162 inhabitants. This was the reason why the rural population still relied considerably on homemade medicines (Sõukand and Raal 2004:1743-1744).

In 1888, the Estonian folklorist and linguist Jakob Hurt (1839-1907) launched his famous appeal to the "active sons and daughters of Estonia" to collect local folklore. Among other requests (to collect songs, myths, beliefs etc), he listed 54 vernacular plant names (with the Latin equivalent supplied for some) and asked people to send popular descriptions of their use, initiating a long-lasting collecting tradition, as well as laying the foundation for future research. Since that time, about 1.5 million pages of general folklore have been stored in the Estonian Folklore Archives, of which about 8800 texts on herbal folk medicine (covering the period 1868 to 1994) have been selected and digitized during the project of Historical Estonian Herbal Medical Database (HERBA), headed by the current authors. Digitized texts were categorized by vernacular names and ailment keywords in the Internet based database. The argumentation in this paper is based primarily on the digitized herbal lore (Sõukand and Kalle 2008) and the personal fieldwork of the authors during the summer of 2009 in several parts of Estonia, during which 30 subjects were interviewed.

\section{Herbal landscape: the ecosemiotic approach to the interaction of humans and medicinal plants}

Until recently, most landscape definitions in the western world were based on soil, climatic, or physiographic features and did not integrate humans as a part of the landscape (Jobin et al. 2003). Recent decades have brought significant changes: If landscape is approached from the human viewpoint, it can be defined as a vision that people acquire by looking around - a definition that, despite being too simple and trivial at a first sight, opens a new ecological perspective of cognition of the landscape (Farina and Belgrano 2006). Bringing the human dimension into landscape theory allows the development of several conceptual frameworks that can help to model and analyze the interactions of humans with their environment. For example, the therapeutic landscape, the concept developed by health geographers, is a remarkable tool for the analysis of the contribution of physical, social, and symbolic environments to physical and mental health and well-being (Gesler 2009). The model of cultural landscape proposed by Italian ecologist Almo Farina emphasizes: "the relationships between human activity and 
the environment have created ecological, socioeconomic, and cultural patterns and feedback mechanisms that govern the presence, distribution, and abundance of species assemblages" (Farina 2000). This leads to the notion of ecosemiotics that can be defined as the semiotics of the relationship between nature and culture, which deals with the semiosis going on between a human and its ecosystem or a human in one's ecosystem (Kull 1998:350).

The concept of herbal landscape goes far beyond the understanding of physical landscape. Herbal landscape is a mental field established within specific cultural and climatic zones. It opens a new perspective: a natural object (plant) is related to the local human by a bond of confidence: indigenous people have learned to trust locally growing plants to the extent that they use them for healing. The perception of herbal landscape requires the presence of some health-threatening situation or a need for prophylactics. This corresponds to an example cited by Farina, when he describes his eco-field hypotheses of landscape as a semiotic interface between organisms and resources: when an organism is hungry, a sign of food presence is quickly identified, even when a low level of food availability is offered (Farina 2008:79).

By using specific plants for his or her health needs, a person creates a personal herbal landscape. The path within this landscape is laid down by personal or learned experiences; patterns are formed according to the images plants have been assigned in socio-cultural traditions. Personal experience derives from an earlier interaction with plants and nature, suffered illnesses, etc. Learned experience requires someone to guide: some elder relative or friend, a doctor or pharmacist, or even a book, or advice given in the media. If a person experiences a positive outcome with a learned experience, it may become a personal experience, the personal path. Herbal landscape can be characterized as a local perception of nature. Hungarian ethnologist Mihály Hoppál argues that national cultures, which from a global perspective can also be considered together with local cultures, have succeeded in developing a feeling of belonging to a home location and its near surroundings. According to Hoppál this local identity primarily means the appreciation of the surroundings and a constant recreation of self-identification related to this home location (Hoppál 2008:168).

According to several natural and cultural boundaries, it can be divided into specific smaller units. This explains how original knowledge of plants gleaned by one set of inhabitants may be clearly distinguished from that of close neighbors. The natural boundaries are, for example, the habitat (community) and geographical range limit of plants. Cultural boundaries are, for example, the cultural space that influences the person, the peculiarity of a given language, and the availability of education, popular books and other media regarding plant use.

\subsection{The plant as an object, the sign as a representamen}

Entering a herbal landscape (either mental or physical or both), we must first perceive the signals from the landscape and then transform them into meaningful signs (Farina 2008) that fit the already existing understandings. A professional 
botanist looking at a plant probably sees specific features that help to detect the species, through the vegetation period. A person looking at a medicinal plant sees the features ascribed to the plant that is supposed to heal (Sõukand and Kalle 2010). The criteria for the features can vary widely; it can be the special appearance of the blooms, leaves, or roots; or its taste, smell, habitat etc. This feature becomes a sign, a representamen sensu Peirce which stands for a person searching the herbal landscape for a plant, creating an interpretant (the vision of the medicinal plant, its preparation, use etc). Although the representamen stands for its object, the botanical taxon, it represents the taxon only in given conditions (geographical and cultural) (Peirce 1931-1935, 1958: II.228). The representamen for the medicinal plant is perceived only when the plant is approached in such a phase of its vegetation period, when the features seen as representamen are fully developed. For example, for coltsfoot Tussilago farfara used for medicinal purposes, the most known representamen are succulent green leaves, seen in summertime, despite the fact that its blooms are among the first to appear in spring. Although people usually know about the existence of the spring blooms (or even use them), the most used part of the plant is its leaves, and from them the plant got its most common Estonian name paiseleht from paisu- 'expand' and leht 'leaf', i.e. 'a leaf that expands rapidly (in spring)'. A mushroom', the common puffball Lycoperdon perlatum, often recognized and appreciated as a delicious food early in its vegetation period, was seen within the herbal landscape of the 19th century Estonia only when the brown dusting fruit body appeared. For the bilberry Vaccinium myrtillus the representamen are ripe black berries, whereas for the linden Tilia species the representamen are young blossoms, not the fruits or leaves. The folklore text below emphasizes the importance of the blooms:

Linden blooms. Linden blooms are used for making tea, which is good for cough and also stomachache. Tea has to be drunk hot, so it makes you sweat. ERA II 203, 419 (18) < Otepää parish, Vastse-Otepää - Artur Kroon (1938)

Until the late 19th century - early 20th, the inner bark of the linden was used throughout Estonia to make a remedy against burns. It could be collected at every time of the year whenever needed and thus people had to recognize the plant even without the leaves or knowledge of the exact place where the tree grew. Later, when this knowledge was lost, the need to recognize the tree without the blossom disappeared as well.

For Estonian herbal folk medicine, just as for folk medicine in general, it is characteristic that representamen can stand for several objects. A person perceives the object with similar representamen as one interpretant - having no need to distinguish botanical taxons. For example, as the species of Orchis and Dactylorhiza have a root resembling a hand or a paw, they are considered the same, creating in the person the perception of one interpretant. Also coltsfoot was not the only plant, represented by succulent leaves (used to heal boils): several plants, not resembling

\footnotetext{
${ }^{1}$ Mushrooms are considered plants in this study and they are included in HERBA.
} 
coltsfoot, were ascribed to have such a feature, e.g. woolly burdock Arctium tomentosum, greater plantain Plantago major, etc (see Figure 1).

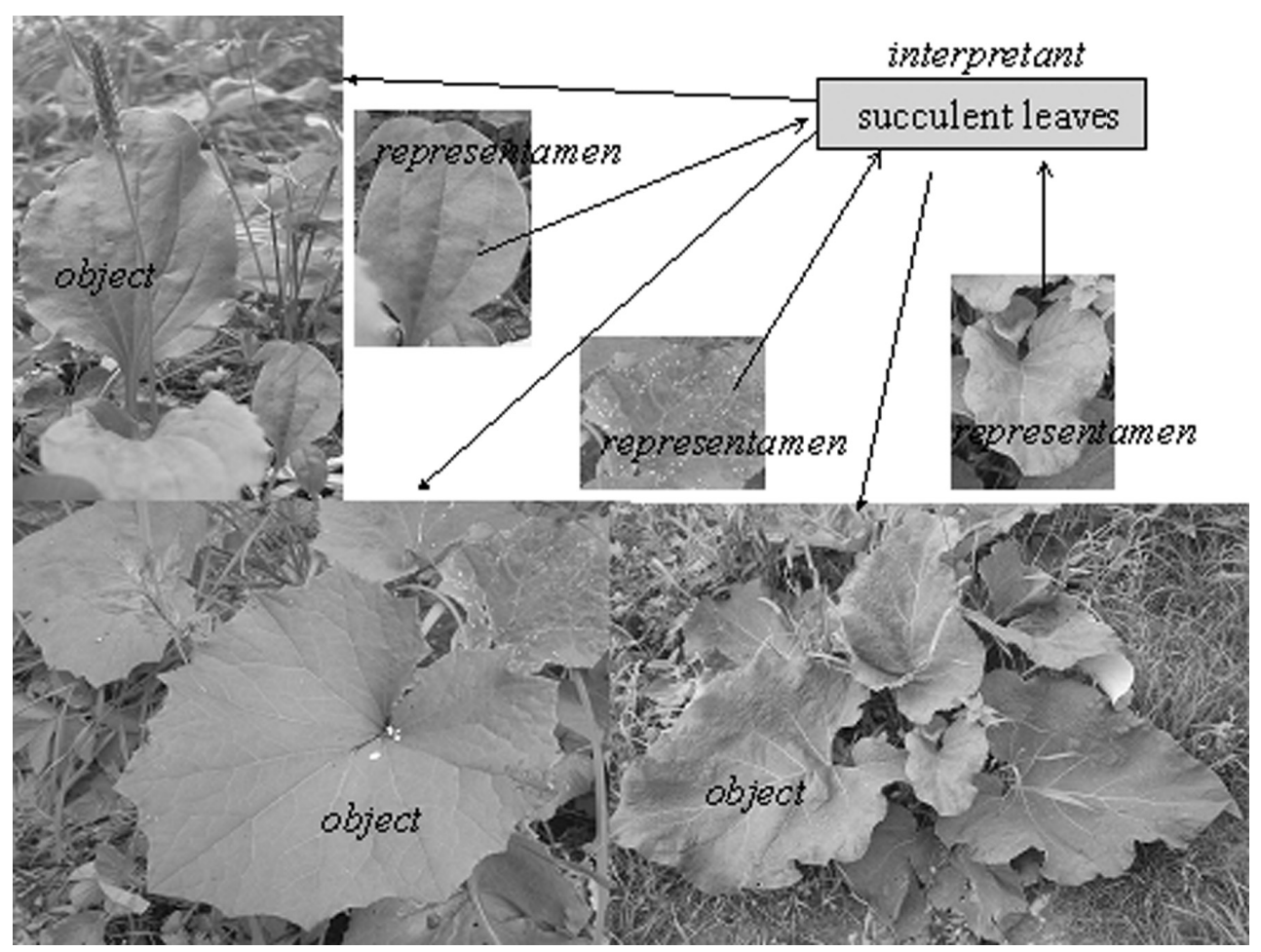

Figure 1. Three different plant species: coltsfoot, woolly burdock and greater plantain can be perceived as having one interpretant (the succulent leaves).

\subsection{Natural boundaries of herbal landscape}

\subsubsection{Habitat}

One possibility to define natural boundaries of an herbal landscape is to look at the habitat of the used species. Our findings agree with the suggestion that plant knowledge and intensity of plant use diminish with distance traveled from human settlements (Martin 2004), and with the statement that people tend to choose for healing those plants that grow in their near surroundings, and indicate that they apply not only to individual plant species but also to entire vegetation communities (Thomas et al. 2009a). Moreover, we found that people choose those plants for healing that not only tolerate human activities (hemeradiaphors), but $40 \%$ of used species prefer moderate to strong human impact and communities changed by human activities (apophytes); 23\% of plant taxons are anthropophytes - either aliens or those run wild from cultivation or otherwise surviving only in communities significantly changed by human activities (see Figure 2). 


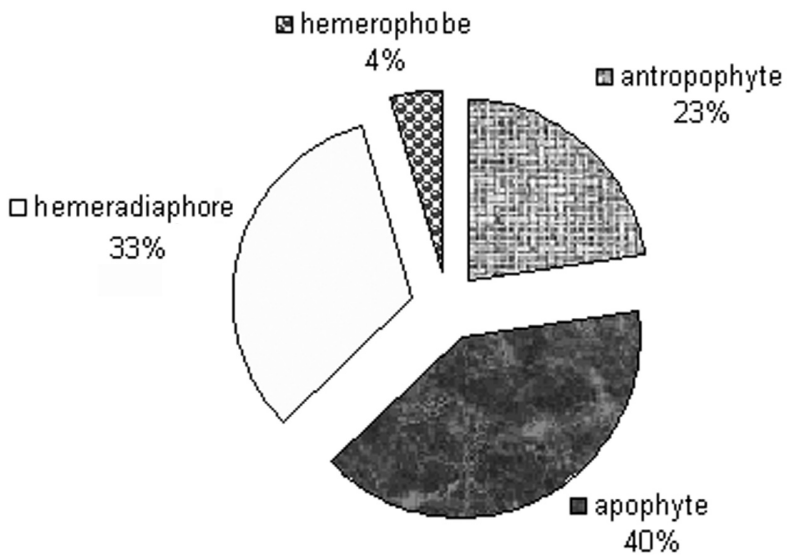

Figure 2. The sensitivity to human impact of taxa potentially used for healing purposes in Estonia. (Based on: Sõukand and Kalle 2008)

The closer a plant grows to a human settlement, the more extensive is its use. Often the habitat of a plant is described as situated in a home forest, home meadow, or home field - the territory belonging to someone's personal space. The territory existing outside this familiar space is terra incognita, visited only on special occasions such as logging or other tasks. On these occasions, plants growing further away were collected, and often used in situ. The following text shows that people often had several alternatives for treating one disease. The plant closest to hand was used, and more distant plants were only picked when people happened to be in their habitat site for some other reason:

Warts and furuncles were treated with sundew [huulhein 'lip's hey'] and celandine [vereurmarohi from vere blood's + urma of bleeding wound + rohi grass, herb]. Sundew was collected when one went to pick cloudberry or working with peat in bog. In our neighborhood there was a big swamp Prillisoo; cranberries were growing there. Sundew grew there also. Now the swamp has disappeared because of the Estonia mine, along with cranberries and sundews. RKM II 380, 18 (14) < Jõhvi parish, Ohakvere v. - Elga Valter, b. 1925 < mother, Juliette Porkon (1984)

On the other hand, until the end of the 19th century, when magical use of herbs was still practiced, plants were brought on purpose, from more distant places:

If a child has pimples, go to the neighboring manor-land and bring some Witch's broom [tuulepesa 'nest of the wind'], burn it, give the water to the child to drink and wash him with this water [with ashes]. E 45695 (9) < Martna parish Matthias Johann Eisen

The reason for the considerable prevalence of anthropophytes and apophytes in the landscape may lie in the distant past, when the early human settlements developed after the end of the Ice Age and started to shape the surrounding environment. Human beings are indeed greater designers than all other living creatures and this reshaping began as soon as humans arrived in our geographical 
area. The reorganization of nature increased during the growth in agriculture in the middle Neolithic period (approx. 3000 BC). In the late Iron Age (1050-1227 AD) the territory of present-day Estonia was most densely covered with anthropogenic lands (including seminatural areas) compared to all earlier history (Kriiska 2004: 22-24, 43). Flora adapted to human influence and plant groups (apophytes and athropophytes) that expanded here from other climatic zones developed slowly, mostly with the help of humans, who either intentionally or involuntary brought plants that to a greater or smaller extent need human disturbance for their survival. Human disturbance helped to develop rich biomes, because herding and mowing limited the growth of dominant species (Sammul 2004:130). The larger the number of plants available in the near surroundings, the greater was the number used by humans for medicinal purposes. Such human-made richness in seminatural areas can be observed only in the conditions of extensive agriculture, prior to the 1940s in Estonia, since most of the plants growing in herded and mowed meadows prefer moderate human impact and greater intensity of human intervention is unfavorable for them (Kukk 1999:59).

Since the second half of the 20th century, the expansion of intensive agriculture due to collectivization and urbanization resulted in the decline or even disappearance of native species (Kukk and Kull 2006:15). Plants growing in the close vicinity of industrial landscapes were abandoned as medicinal plants with the growth in the awareness of the dangers caused by pollution. Forced collectivization narrowed the notion of home, leaving only a very small kitchen garden or yard for personal use.

However, the contraction of the personal herbal landscape had already begun earlier. The bearers of Western cultural thought, the Baltic Germans, introduced the culture of gardening to local peasants long before the beginning of collectivization. Since native inhabitants had no need to grow medicinal plants (Kalle 2007), the manor gardens are remembered as places where many unknown and useless plants were growing (Banner 2007:139). The first attempts to establish farm gardens were made at the end of the 19th century, when the recently freed serfs had the chance to by land for perpetuity. The real shift in mentality took place in the 1920s, when the establishment of farm gardens was encouraged, and later, in the 1930s, it even became a question of pride, since the most beautiful homes were singled out for an award (Banner 2007 and Viires 2000). From the point of view of the herbal landscape, the richness achieved as a by-product of everyday activities over a greater area was now replaced by goal-seeking activity on a considerably smaller piece of land.

Here, the question may be raised, whether the diagram in Figure 2 should change along the time-scale. The answer is that the proportion of plant taxa used according to human influence remains almost unchanged during the period (18681994) covered with digitized herbal lore, differing only by $1-2 \%$. Although the lists of the plants used at different times look quite different, the plants with similar sensitivity to human impact substitute each other, and thus the percentage stays on the same level. 
The newly established gardens also became sites for growing native species that might not have grown in this particular area and whose use is not reflected in earlier folklore. Good examples of medicinal plants introduced to gardens are motherwort Leonurus cardiaca, common comfrey Symphytum officinale, and absintium Artemisia absinthium. Figure 3 presents the geographical cultural map indicating the use of absintium. Naturally, absintium grows around dwellings, on dry, sandy or stony soils, mostly in coastal areas and on islands (Kukk and Kull 2005:279, see also Figure 4). Comparison of the two maps shows that absintium was mostly used in areas, where it did not grow naturally, indicating the cultivation of the plant.

Other good examples are some berries, naturally growing throughout Estonia, such as blackcurrant Ribes nigrum and raspberry Rubus idaeus, which were initially just collected from the areas around dwellings. Later their growing area moved out of the new perception of the herbal landscape and they were brought into gardens in the form of new and improved varieties (often imported), thus continuing to be a part of the perceived herbal landscape. Also, some introduced plants, earlier almost unknown by local inhabitants, such as marigold Calendula officinalis and garlic Allium sativum that are now widely cultivated and used as medicinal plants. In contrast, some plants lost their value as medicinal plants after being introduced into gardens as cultivated plants. Being decorative cultivars, plants of the stonecrop family Sedum sp., jovibarba Jovibarba globifera, yellow chamomile Anthemis tinctoria are nowadays only rarely mentioned as medicinal plants by older people.

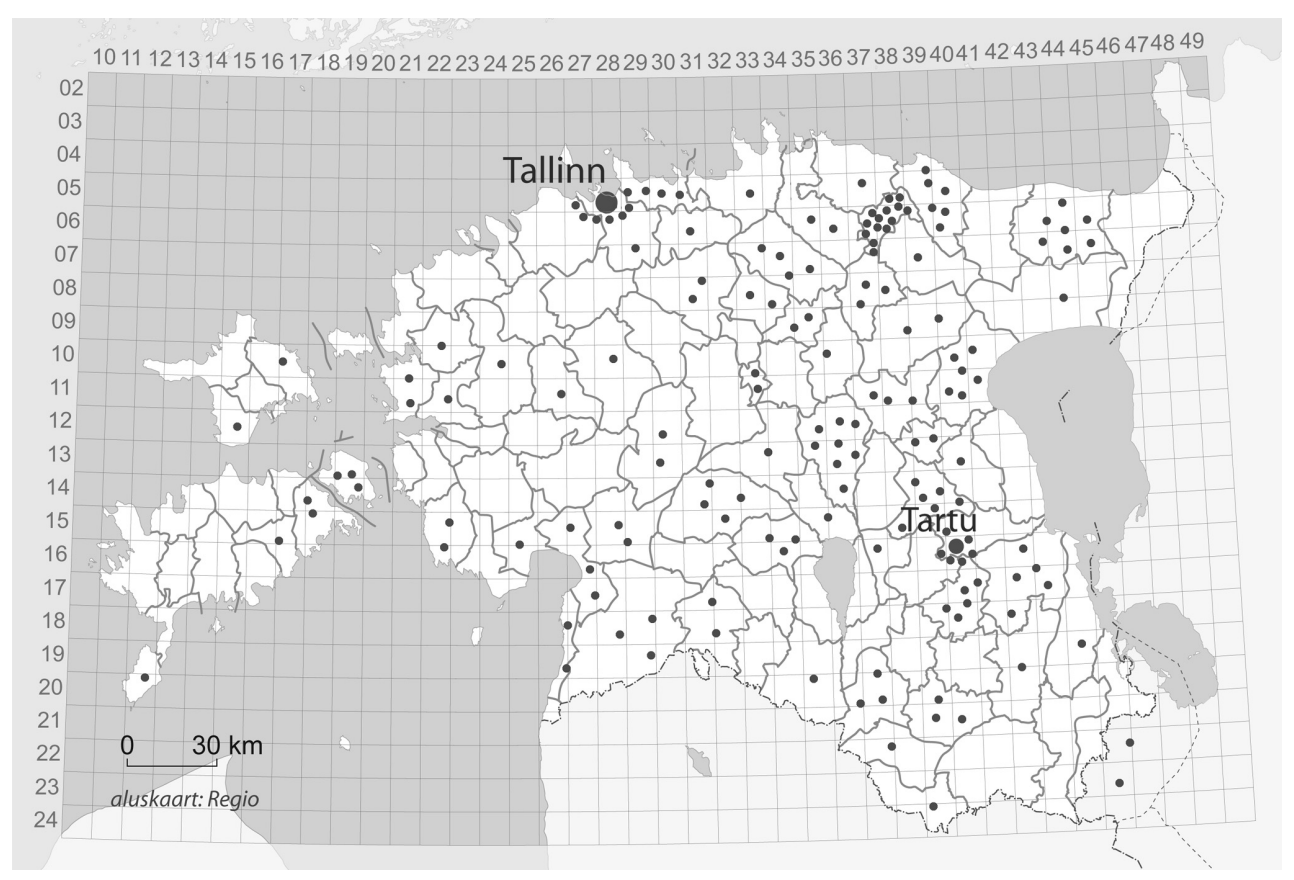

Figure 3. Usage cases of absinthium reported in HERBA (Based on: Sõukand and Kalle 2008). 


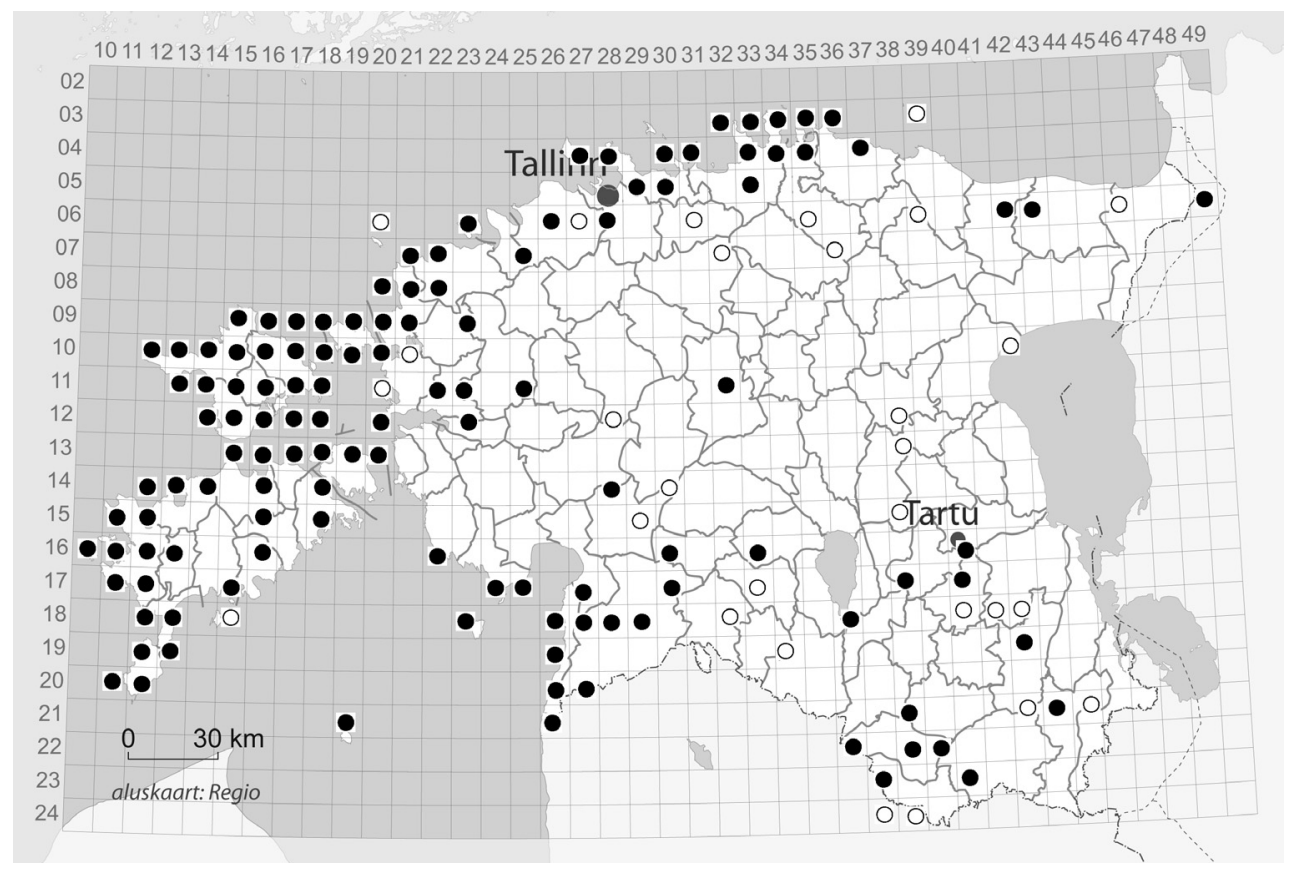

Figure 4. Distribution map of absinthium. Legend: - - The species has been found in 1971-2005, ○ - Distribution data from 1921-1970. (Based on: Kukk and Kull 2005: 528)

\subsubsection{Range limits (plant geography)}

Although Estonia covers a relatively small area, its territory can be divided, according to plants growing on their range limit, into 12 geographical regions (see Lippmaa 1935). The considerable variety of plant regions is the result of a matrix of good water availability, long coastline, and climatic differences in east-west and north-south directions. Plant richness is greatest in the western part of Estonia, decreasing in an easterly direction; at the same time the number of registered species remains the same in the north-south direction (Kull et al 2004:143).

Such a territorial peculiarity must be reflected in the Estonian herbal landscape as well. The authors compared the usage and distribution of two plant species reaching their range limit in different parts of Estonia: leatherleaf Chamaedaphne calyculata (common in eastern Estonia, Figures 5 and 6) and bog myrtle Myrica gale (common in western Estonia, Figures 7 and 8).

The results show that range and reported usage cases coincide geographically. This allows us to conclude that range limits have an influence on the boundaries of the herbal landscape. 


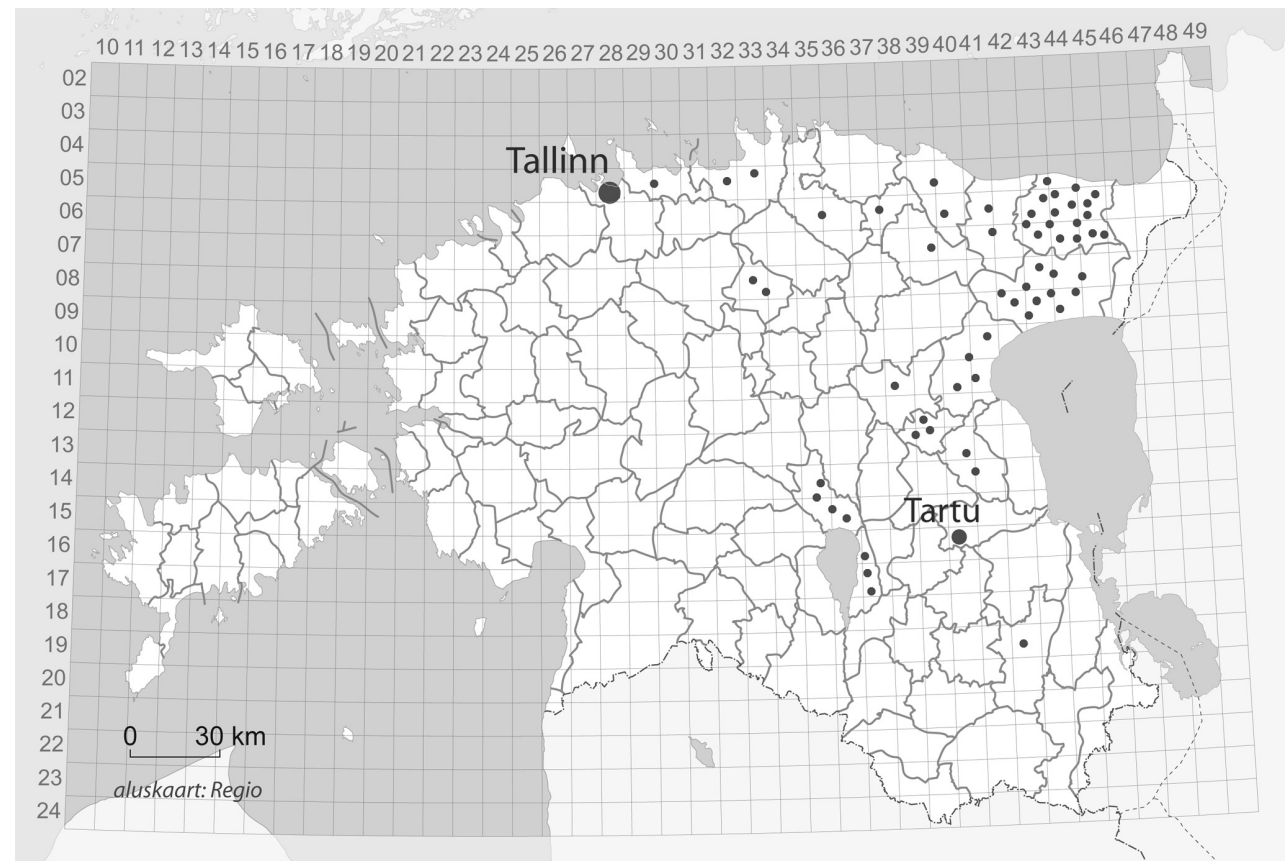

Figure 5. Usage cases of leatherleaf reported in HERBA (Based on: Sõukand and Kalle2008).

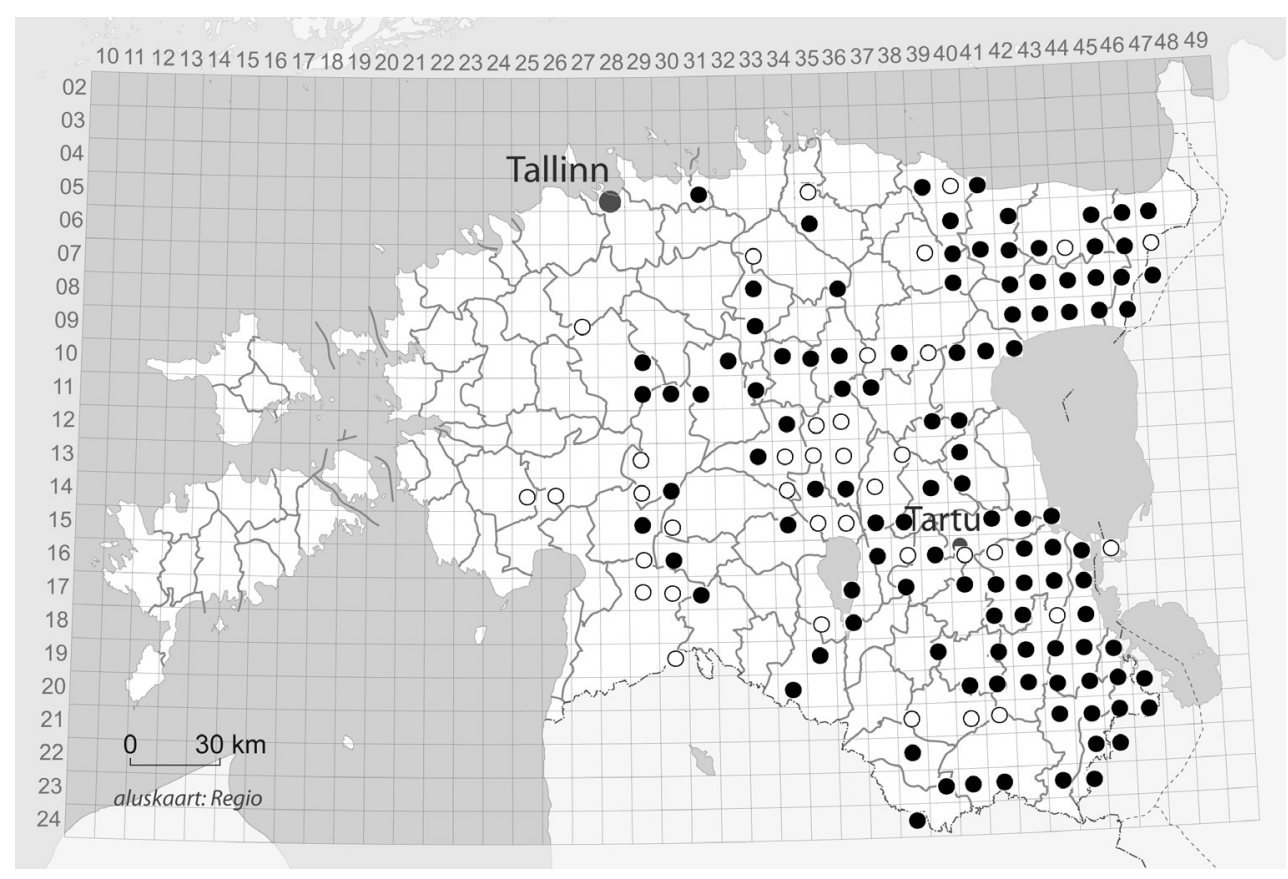

Figure 6. Distribution map of leatherleaf. Legend: • - The species has been found in 1971-2005, ○ - Distribution data from 1921-1970. (Based on: Kukk and Kull 2005:183) 


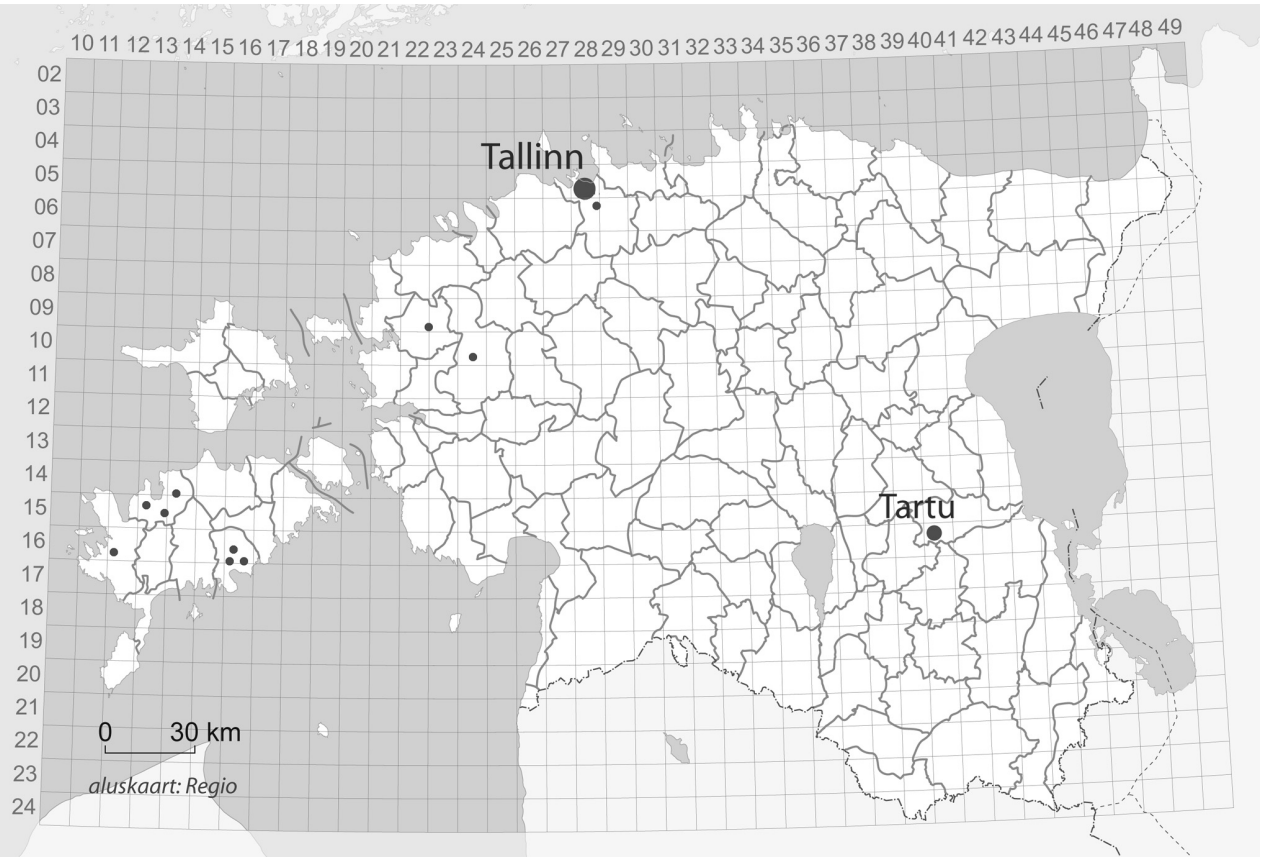

Figure 7. Usage cases of bog myrtle reported in HERBA (based on: Sõukand and Kalle 2008).

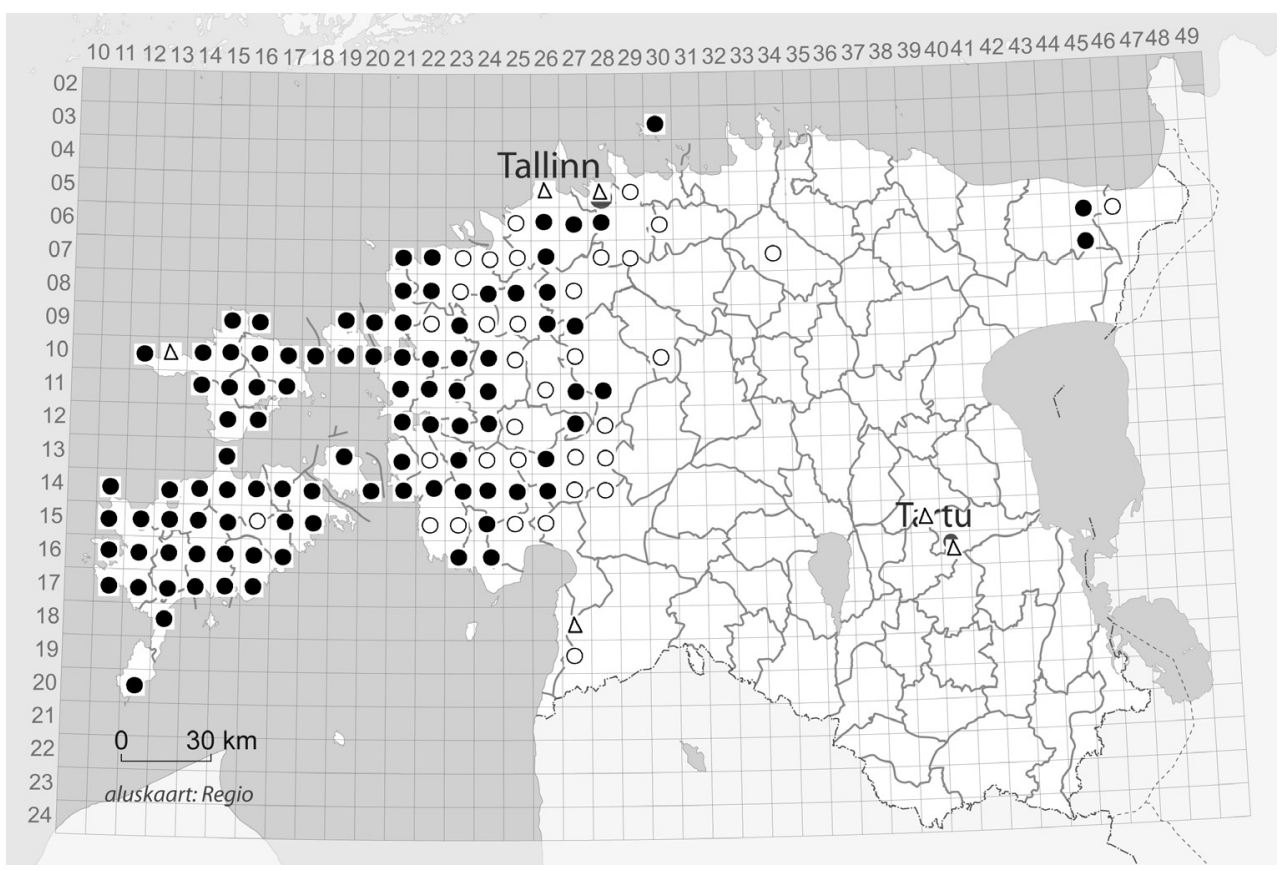

Figure 8. Distribution map of bog myrtle. Legend: • - The species has been found in 1971-2005, ○ - Distribution data from 1921-1970. $\Delta$ - Distribution data pre 1921. (Based on: Kukk and Kull 2005:238) 


\subsection{Cultural borderlines}

\subsubsection{Local and global}

Cultural boundaries of herbal landscape can be better understood, if the notion of local and global herbal lore is used (Kalle and Sõukand 2010). Local herbal lore is related to native plants and requires direct contact with a person possessing the relevant knowledge at the moment when the medicinal plant is needed. The person seeking help acquires the knowledge passed down through generations, continuing in this way the local herbal tradition. The transferred knowledge is personal; learning takes place most likely in a natural context. The knowledge of pathways in the herbal landscape is therefore also acquired and the herbal landscape of the elder generation becomes that of the younger generation as well. Such communications cause considerably fewer misunderstandings than other ways of acquiring herbal knowledge. However, the required plant may not always be at hand (the wrong time of the year, wrong place, etc). In these cases the description of the plant was provided, as well as an indication of its growing site. Such descriptions may reveal different representamen, presenting, for two communicating sides, different objects growing in the same place, as they may share joint interpretants. Such an exchange of information can create the situation where several similar (or growing in the same location) plants are in the same village used for one disease group. If a plant sample, the object, is provided, this can reduce the likelihood of errors.

Global herbal lore is based mostly on non-native species and sometimes adds new uses to local plants. The global herbal knowledge usually spreads via books, or contemporary media such as television and the Internet. Almost all popular medical books in Estonian have introduced global knowledge on herbal use (with a few exceptions). Healing practices learned from books or other visual or audio sources require much more interpretation of the written (heard) text and of thedepicted plant. This can potentially lead to many misunderstandings, not only in the methods of use, but also in the identification in the field of the plant described or depicted in the source. On the other hand, the more the plant discovered from the book is used and its use conveyed to others in the community, the more local this knowledge becomes and the more this plant use becomes a part of the community herbal landscape. A good example of such integration of global knowledge into local herbal landscape is the case of arnica - the plant itself (Arnica montana) has never grown in Estonia, but several local species have been attributed its name (Sõukand 2007, Sõukand and Raal 2008).

\subsubsection{Local herbal landscapes within Estonian historical parishes}

Lutheran church parishes (kihelkond) are historical territorial units that were in wide use until the 1920s; even today many people identify with their home-parish. The division into parishes is used in linguistics (to delimit sub-dialects), in ethnography, folkloristics, etc, and should be used in historical ethnobotanical research as well. According to the data presented in HERBA, herbal lore also 
differs strongly in cultural space, and the differences mostly remain within parish borders (Sõukand and Kalle 2008). A community living for generations in one settled place developed the habit of using specific plants out of many possible alternatives that might heal a concrete disease. Within another nearby community, the same plants present in nature may be abandoned in favor of other alternatives. Thus the local range of the utilized plants is rather restricted, while nationwide herbal use is very diverse. As an example, folk medicinal use of meadowsweet Filipendula ulmaria is presented in Figure 9.

Although meadowsweet is common throughout Estonia, growing in moist meadows, woody meadows, marshes and bogs (Leht 2007:147), it is used only in 17 parishes out of 107 . In some parishes where the plant was already familiar, it has been used for several purposes. The plant was known throughout the country, as the names angervaks and vorm were common in almost every parish; although the plant also has specific names in some parishes, only one of them, naba-arnikas indicated its medicinal use (see Figure 10).

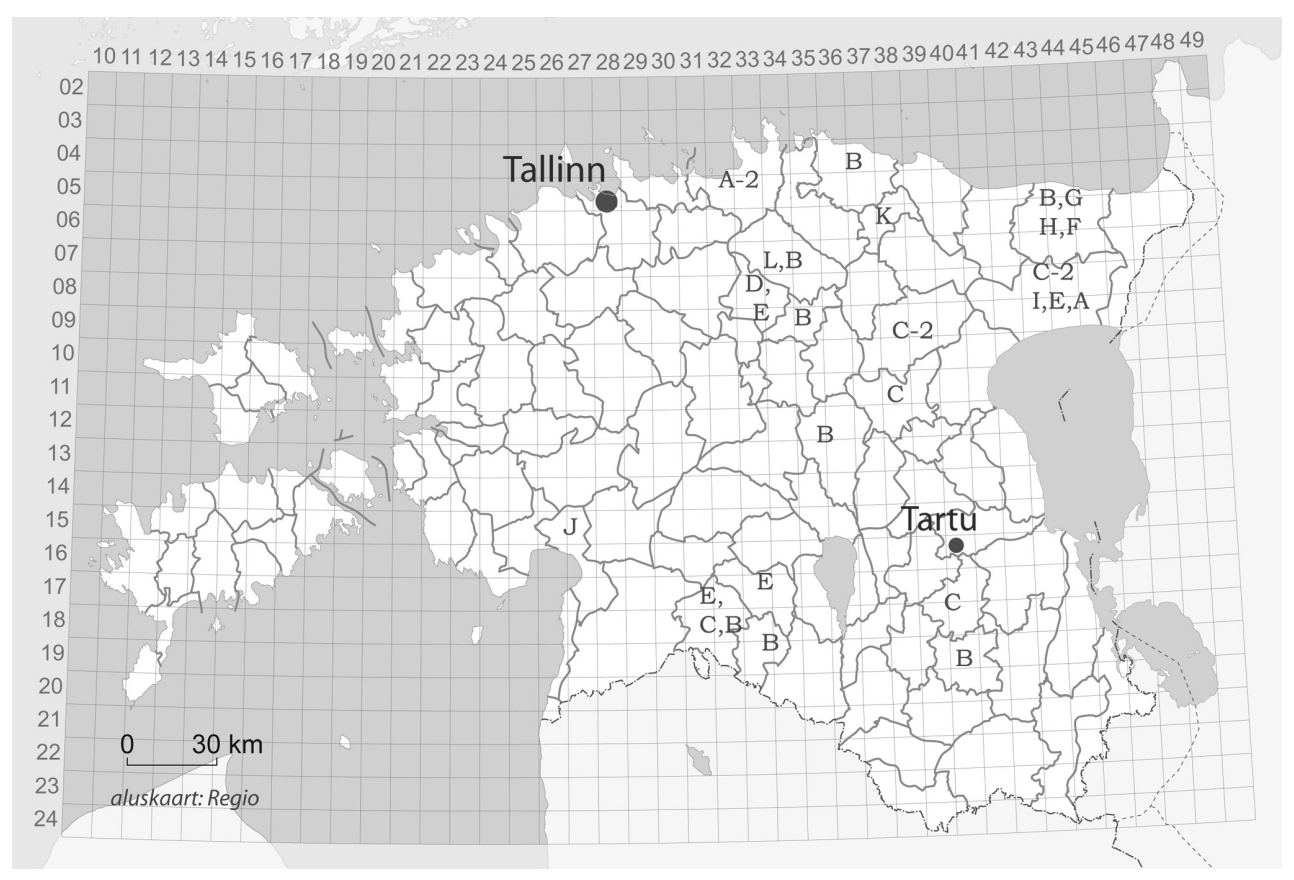

Figure 9. Folk medical use of meadowsweet. Abr: A - tuberculosis, cough; B - problems with menstruation; $\mathrm{C}$ - digestive problems; $\mathrm{D}$ - straining (venitus); $\mathrm{E}$ - stomach ache; $\mathrm{F}$ - heart disease; $\mathrm{G}$ - skin disease; H - headache; I - rheumatism; J - oedema; $\mathrm{K}$ - rabies; L - bedbugs (Based on: Sõukand and Kalle 2008). 


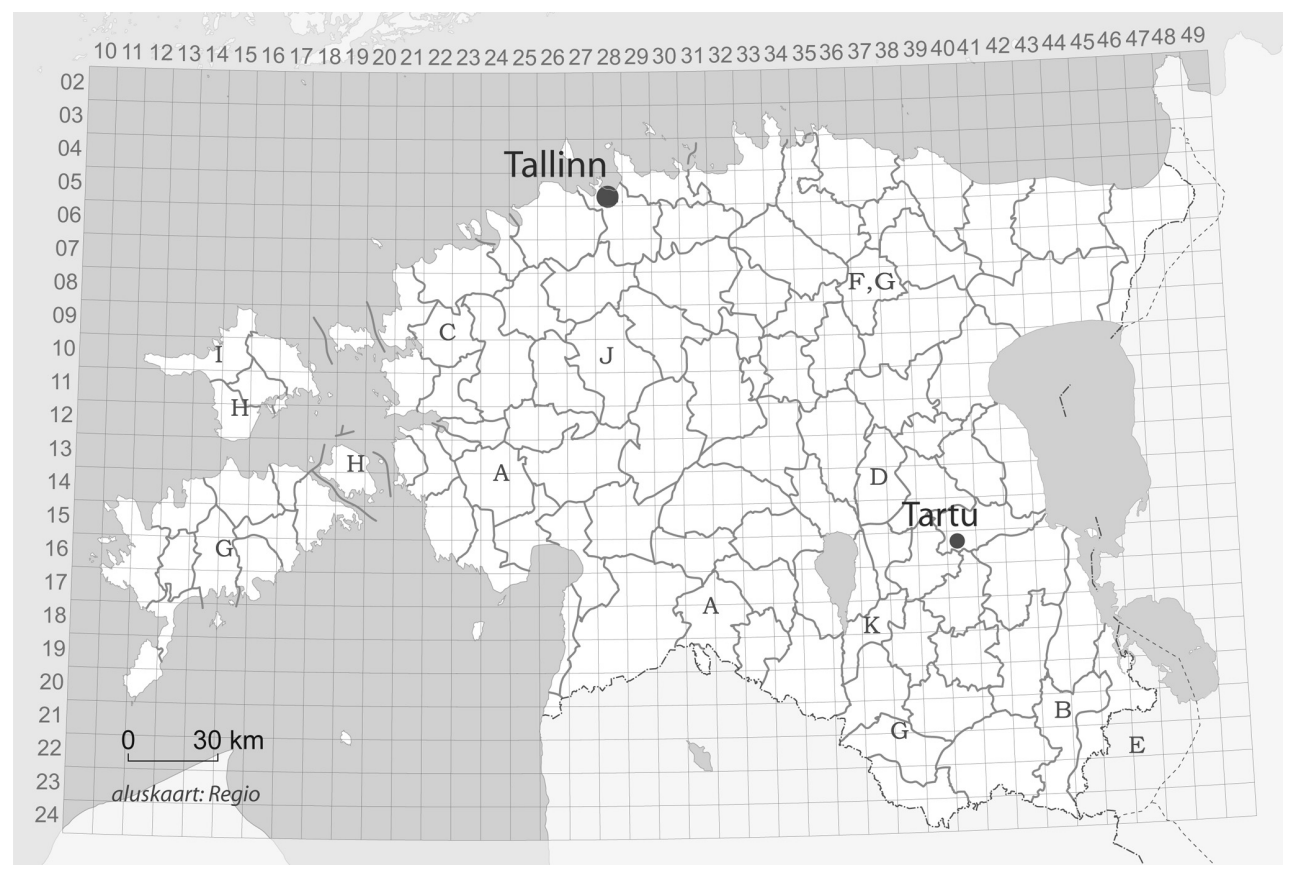

Figure 10. Common names of meadowsweet. Angervaks and vorm are generally used names, but others are: A - hobusehurmarohi, hobusekuserohi, B - maarjaõis, C - naba-arnikas, D - püstid, E - retelhain, F - risthammas, G - seanaarid, -rohi, seanaeris, $\mathrm{H}$ - tuulerohi, I - varsiged, J - võmmid, K - õnerhain (Based on: Vilbaste 1993: 317-318).

\section{Perspectives}

For future research into the Estonian historical herbal landscape, closer attention should be paid to the origin of the knowledge of plant use, as it may play a crucial role in the identification of the plant and may help to understand the perception of herbal landscape in certain regions and in the population as a whole as well. It is important to note that, within historical Estonian herbals, only a few writers have documented folk medical botany according to cultural differences. Two of them describe the use of herbal medicine on the island of Saaremaa: a noteworthy study written by amateur botanist and local pastor Johann Wilhelm Ludwig von Luce 1750-1842 (1823) and a later study, published over a hundred years later, written by pharmacist Julius Tõll (1929). A third author, Gustav Vilbaste (1885-1967), pioneer of Estonian ethnobotany, documented with great precision the places of origin of the described uses; unfortunately, he published only two volumes of a proposed 5-volume book (Vilberg 1934-1935). Still, collected lore on Estonian folk herbal medicine has been used by other authors as well. For example stud. med. Jaan Lääts collected herbal medical lore from Põltsamaa parish. Although the book (Lääts 1937) based on this collection was reprinted in five editions during two years, becoming very popular, he never 
claimed to have used either ethnobotanical knowledge or its origin. Moreover, even the only herbal published (in five editions) during the Soviet period, coedited by G. Vilbaste and indicating folk use of officially recognized medicinal plants, does not mention the place of origin for the listed uses (Kook and Vilbaste 1962, Tammeorg et al. 1984).

Herbals store many times more information than one person requires or can use. This makes the orientation in the herbal landscape rather complicated; on the other hand, the description of many different options provides more possibilities for healing. Once the plant is chosen and used, it becomes part of the personal landscape of the user, and later on, if the information about its use has spread in the community, the new plant becomes a part of the community herbal landscape, as happened with arnica. Global knowledge conveyed by modern herbals is based on the active substance of the plant, totally unlike the folk medical approach of using the whole plant. Modern herbals include photos indicating the useful parts of the described plants, often omitting the full view of the plant. This ensures that the plant will only be recognized in the 'right' vegetation period, being often even more misleading than folk representamen for plants. Creating new folklore, such books produce a new generation of users of book-based herbal landscapes, who may never actually pick any plant, as they are not able to really recognize it in nature.

Like plant use learned from books and/or purchased from pharmacies, the cultivation of plants in gardens reflects the same principle of human longing for habitual coexistence with plants, and replaces the once broken traditional chain of knowledge transmission. Modern gardening expects the establishment of a garden that includes several specific parts (herbs, spices, flowers, etc), and one plant can serve several purposes, for example, marigold Calendula officinalis and sweet violet Viola odorata are used as decorative and medicinal plants. On the other hand, varieties resembling local traditional medicinal plants, for example, varieties of yarrow Achillea millefolium, inhabit flower gardens, but they are no longer used as medicinal plants. Such a new, narrowing approach to the herbal landscape, habituating only in the garden, brought along new medicinal uses for plants already cohabiting with humans, but previously not accepted as medicinal. Good examples are lilac Syringa $s p$ and horse-chestnut Aesculus hippocastanum, cultivated in Estonia since the end of the 18th century, but not mentioned in herbal medical lore until the 1930s. Here, ecosemiotic gardening (a notion proposed by Maran 2004) would offer possibilities for retaining traditional plants in human surroundings without changing them into passive beauty.

How narrow will the modern herbal landscape become? For some devoted gardeners it will remain within their garden; for some people, not having land for a garden, it will be limited to a room where plants are grown in pots (like Aloe $s p$, Pelargonium graveolens, or Capsicum annuum). For those who do not trust themselves to recognize plants in nature, herbal landscape shrinks to the shelf of the pantry where they store dried plants bought from the pharmacy. Nevertheless, at least in Estonia, there are still many who retain the vision of the herbal 
landscape inherited from their ancestors. Although some paths in it might be laid down by books or other media, it is still worthy of research.

\section{Acknowledgements}

The authors acknowledge the Research and Development program Estonian Language and Cultural Memory (EKKM09-84) at the Estonian Ministry of Education and Research, Estonian Science Foundation Grant no 6669, EEA/EMP Grant no 54 MP1RT08079N and the European Union through the European Regional Development Fund (Center of Excellence CECT) for supporting this research. Our special thanks to Sabine Brauckmann, Toomas Kukk, Kalevi Kull, Kati Lindström, Timo Maran and Ilmar Part for their help with different aspects of the work.

Addresses:

Renata Sõukand

Department of Semiotics

Institute of Philosophy and Semiotics

Tartu University

Tiigi tn 78

51003 Tartu, Estonia

Tel.: +372 5022394

E-mail: renata@folklore.ee

\section{Raivo Kalle}

Estonian Literary Museum

Vanemuise 42

51003 Tartu, Estonia

Tel.: +372-55660367

E-mail: raivo@folklore.ee

\section{References}

Ali-Shtayeh Mohammed S., Zohara Yaniv, and Jamal Mahajna (2000) "Ethnobotanical survey in the Palestinian area: a classification of the healing potential of medicinal plants". Journal of Ethnopharmacology 73, 221-232.

Banner, Anneli (2007) “"Pruunid põsed ju õunul ja hõrakail...” (H. Visnapuu). Aiapidamise tähendusest Muhu näitel”. [Meaning of gardening by Muhu example.] Suitsutare 4: valitud artiklid, 137-169. [Chimneyless hut: selected articles.] Maret Tamjärv, ed. Tallinn: Eesti Vabaõhumuuseum.

Bennett, Bradley C (2007) "Doctrine of signatures: an explanation of medicinal plant discovery or dissemination of knowledge?". Economic Botany 61, 246-255.

Dafni, Amots and Efraim Lev (2002) "The doctrine of signatures in present-day Israel". Economic Botany 56, 328-334.

De Natale, A., G. B Pezzatti, and A. Pollio (2009) "Extending the temporal context of ethnobotanical databases: the case study of the Campania region (southern Italy)". Journal of Ethnobiology and Ethnomedicine 5: 7. 
Eyssartier, C., Ladio, A. H., and Lozada, M. (2008) "Cultural transmission of traditional knowledge in two populations of north-western Patagonia". Journal of Ethnobiology and Ethnomedicine 4: 25.

Farina, Almo (2008) "The landscape as a semiotic interface between organisms and resources". Biosemiotics 1, 75-83.

Farina, Almo (2000) "The cultural landscape as a model for the integration of ecology and economics". Bioscience 50, 313-320.

Farina, Almo and Andrea Belgrano (2006) "The eco-field hypothesis: toward a cognitive landscape". Landscape Ecology 21, 5-17.

Gesler, W. M. (2009) “Therapeutic landscapes”. In International encyclopedia of human geography, 229-230. Rob Kitchin and Nigel Thrift, eds. Oxford: Elsevier.

Giday, Mirutse, Zemede Asfaw, Thomas Elmqvist, and Zerihun Woldu (2003) "An ethnobotanical study of medicinal plants used by the Zay people in Ethiopia". Journal of Ethnopharmacology $85,43-52$.

Guarrera, P. (1999) "Traditional antihelmintic, antiparasitic and repellent uses of plants in central Italy". Journal of Ethnopharmacology 68, 183-192.

Hoppal, Michaly (2008) Etnosemiootika. [Ethnosemiotics.] Tartu: EKM Teaduskirjastus.

Jarić, Snežana, Zorica Popović, Marina Mačukanović-Jocić, Lola Djurdjević, Miroslava Mijatović, Branko Karadžić, Miroslava Mitrović, and Pavle Pavlović (2007) "An ethnobotanical study on the usage of wild medicinal herbs from Kopaonik mountain (central Serbia)". Journal of Ethnopharmacology 111, 160-175.

Jobin, Benoît, Jason Beaulieu, Marcelle Grenier, Luc Bélanger, Charles Maisonneuve, Daniel Bordage, and Bernard Filion (2003) "Landscape changes and ecological studies in agricultural regions, Québec, Canada". Landscape Ecology 18, 575-590.

Kalle, Raivo (2007) "Naturaliseerunud ravimtaimed etnobotaanika vaatenurgast (hariliku katkujuure, hariliku siguri, aedvaagi, aed-mädarõika, hariliku seebilille ja lõhnava kannikese näitel)". [Naturalized medicinal plants from the viewpoint of ethnobotany: the example of butterbur, chicory, elecampane inula, horseradish, soapwort and sweet violet] Mäetagused (Tartu) 36, $105-128$.

Kalle, Raivo and Renata Sõukand (2010) "Sissevaade eestlaste ravimtaimede tundmise mitmekesisusse". [Insight into diversity of the herbal knowledge of Estonians] Mäetagused (Tartu). 45, 77-94.

Kook, Oskar and Gustav Vilbaste (1962) Eesti NSV ravimtaimed. [Estonian medicinal plants.] Tallinn: Valgus.

Kull, Kalevi (1998) "Semiotic ecology: different natures in the semiospehere". Sign System Studies 26, 344-371.

Kull, Tiiu, Tõnu Möls, and Kalevi Kull (2004) "Eesti taimegeograafiline liigendus ja liikide informatiivsus". [Phytogeographical districts of Estonia and the informativeness of species] Eesti Loodusuurijate Seltsi Aastaraamat. Year-book of the Estonian Naturalists' Society (Tartu) 82, 132-156.

Kukk, Toomas (1999) Eesti taimestik. [Vascular plant flora of Estonia.] Tallinn: Teaduste Akadeemia Kirjastus.

Kukk, Toomas and Tiiu Kull (2006) "Globaalne ja lokaalne eesti taimestik". [Global and local Estonian vascular plant flora.] In Lehed ja tähed: looduse ja teaduse aastaraamat, 10-17. [Leaves and stars: yearbook of nature and science] Indrek Rohumets, ed. Tallinn: Loodusajakiri.

Kukk, Toomas and Tiiu Kull, eds. (2005) Eesti Taimede Levikuatlas. Atlas of the Estonian Flora. Tartu: Eesti Maaülikool.

Kriiska, Aivar (2004) "Inimene ja loodus esiajal". [Human and nature in prehistory.] In Pärandkooslused: õpik käsiraamat, 13-47. [Seminatural communities: textbook] Toomas Kukk, ed. Tartu: Pärandkoosluste Kaitse Ühing.

Leht, Malle (2007) "Sugukond roosõielised - Rosaceae". [Family Rosaceae.] In Eesti taimede määraja. 2., parandatud ja täiendatud trükk, 145-166. [Manual of Estonian plants.] Malle Leht, ed. Tartu: Eesti Maaülikool. 
Lippmaa, Theodor (1935) "Eesti geobotaanika põhijooni. Aperçu géobotanique de l'Estonie". Acta Instituti et Horti Botanici Universitatis Tartuensis 4, fasc. 3-4.

Lääts, Jaan (1937) "Kodumaa ravimtaimed. Käsiraamat ravimtaimede tundmaõppimiseks ning nende kasutamiseks ravimitena". [Homeland medicinal plants: handbook for learning of medicinal plants and their use for medical purposes] Tartu: Ilutrükk.

Lira, Rafael, Alejandro Casas, Rocío Rosas-López, Martín Paredes-Flores, Edgar Pérez-Negrón, Selene Rangel-Landa, Leonor Solís, Ignacio Torres, and Patricia Dávila (2009) "Traditional knowledge and useful plant richness in the Tehuacán-Cuicatlán valley, Mexico". Economic Botany 63, 271-287.

Liu, Y., Z. Dao, C. Yang, Y. Liu, and C. Long (2009) "Medicinal plants used by Tibetans in Shangrila, Yunnan, China". Journal of Ethnobiology and Ethnomedicine 5: 15.

Lozada, M., A. Ladio, and M. Weigandt (2006) "Cultural transmission of ethnobotanical knowledge in a rural community of northwestern Patagonia, Argentina". Economic Botany 60, 374-385.

Luce, Johann Wilhelm Ludwig von (1823) Topographische Nachrichten von der Insel Oesel, in medicinischer und ökonomischer Hinsicht. Riga: Häcker.

Maran, Timo (2004) "Gardens and gardening: an ecosemiotic view”. Semiotica 150, 1-4, 119-133.

Martin, Gary J (2004) Ethnobotany: a methods manual. (Earthscan People Plants International Conservation Series.) London: Earthscan.

Masing, Viktor, Jaanus Paal, and Andres Kuresoo (2000) "Biodiversity of Estonian wetlands". In Biodiversity in Wetlands: assessment, function, and conservation, I: 295-79. B. Gopal, W. J. Junk, and J. A. Davis, eds. Leiden: Backhuys.

Molares, S. and A. Ladio (2009) "Ethnobotanical review of the Mapuche medicinal flora: use patterns on a regional scale". Journal of Ethnopharmacology 122, 2, 251-260.

Müller-Schwarze, Nina (2006) "Antes and Hoy Día: plant knowledge and categorization as adaptations to life in Panama in the twenty-first century". Economic Botany 60, 321-334.

Ööpik, Merle, Toomas Kukk, Kalevi Kull, and Tiiu Kull (2008) "The importance of human mediation in species establishment: analysis of the alien flora of Estonia". Boreal Environment Research 13, 53-67.

Peirce, Charles S. (1931-1935, 1958) The collected papers of Charles Sanders Peirce. Reproducing Vols. I-VI, Charles Hartshorne and Paul Weiss, eds. Vols. VII-VIII, Arthur W Burks, ed. Cambridge: Belknap Press of Harvard University Press. CD-ROM.

Raukas, Anto, ed. (1995) Eesti Loodus. Nature of Estonia. Tallinn: Valgus and Eesti Entsüklopeediakirjastus.

Reyes-García,Victoria, Tomás Huanca, Vincent Vadez, William Leonard, and David Wilkie (2006) "Cultural, practical, and economic value of wild plants: a quantitative study in the Bolivian Amazon". Economic Botany 60, 62-74.

Rivera, Diego, Concepción Obón, Cristina Inocencio, Michael Heinrich, Alonso Verde, José Fajardo, and José Antonio Palazón (2007) "Gathered food plants in the mountains of Castilla-La Mancha (Spain): ethnobotany and multivariate analysis". Economic Botany 61, 269-289.

Sõukand, Renata (2007) "Kuidas võõras muutub omaks: kaks taime eesti rahvameditsiinis". [How foreign becomes own: two plants in Estonian folk medicine.] Mäetagused (Tartu) 36, 79104.

Sõukand, Renata and Raivo Kalle (2010) "Plant as object within berbal landscape: different kinds of perception". Biosemiotics 3, 3. DOI 10.1007/s12304-010-9078-9.

Sõukand, Renata and Raivo Kalle (2008) Historistlik eesti rahvameditsiini botaaniline andmebaas (HERBA). [HERBA, the Estonian folk medicine database of plant use.] http://herba.folklore.ee

Sõukand, Renata and Ain Raal (2008) "How the name arnica was borrowed into Estonian". Trames $12,29-39$.

Sõukand, Renata and Ain Raal (2004) "Ravimtaimed Eesti rahvameditsiinis. Ajalooline taust, etnofarmakoloogiliste andmete kogumine ja analüüs". [Medicinal plants in Estonian folk medicine: historical background, collection and analysis of ethnopharmacological data.] Akadeemia (Tartu) 8, 1734-1762. 
Tammeorg, Johannes, Oskar Kook, and Gustav Vilbaste (1984) Eesti NSV ravimtaimed. [Estonian medicinal plants.] Tallinn: Valgus.

Thomas, Evert, Ina Vandebroek, Patrick Van Damme, P Goetghebeur, D Douterlungne, Sabino Sanca, and S Arrazola (2009a) "The relation between accessibility, diversity and indigenous valuation of vegetation in the Bolivian Andes". Journal of Arid Environments 73, 854-861.

Thomas, Evert, Ina Vandebroek, Sabino Sanca and Patrick Van Damme (2009b) "Cultural significance of medicinal plant families and species among Quechua farmers in Apillapampa, Bolivia”. Journal of Ethnopharmacology 122, 60-67.

Tõll, Julius (1929) Saaremaal ja Abruka saarel kasvavad arstirohutaimed. Taimed, mis varemalt arstirohuna tarvitatud ja mis praegu tarvitamisel. [Medicinal plants growing in Saaremaa and Abruka. Plants that have been used and are used up to now as medicine.] Kuressaare: H. Papp.

Vandebroek, Ina, Patrick Van Damme, Luc Van Puyvelde, Susana Arrazola and Norbert De Kimpe (2004) "A comparison of traditional healers' medicinal plant knowledge in the Bolivian Andes and Amazon". Social Science \& Medicine 59, 837-849.

Viires, Ants (2000) Puud ja inimesed. 2nd ed. [Trees and peoples.] Tartu: Ilmamaa.

Vilbaste, Gustav (1993) Eesti taimenimetused. [Plant names of Estonia] (Emakeele Seltsi Toimetised, 20 (67).) Eeva Ahven, Heino Ahven, Erast Parmasto, and Eevi Ross, eds. Tallinn: Emakeele Selts.

Vilberg, Gustav (1934-1935) Meie kodumaa taimi rahva käsitluses. Vols. I.1, I.2 and II. [Plants of our homeland in folk use.] Tartu: G. Roht and K. Mattiesen. 